\title{
Reconnaissance Geology of the Northern Yukon-Koyukuk Province, Alaska
}

GEOLOGICALSURVEY PROFESSIONAL PAPER 774-A

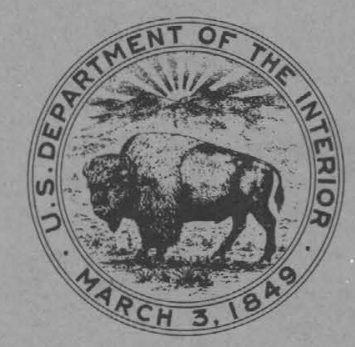





\section{Reconnaissance Geology of the Northern Yukon-Koyukuk Province, Alaska}

By WILLIAM W. PATTON, JR.

SHORTER CONTRIBUTIONS TO GENERAL GEOLOGY

GEOLOGICAL SURVEY PROFESSIONAL PAPER 774-A

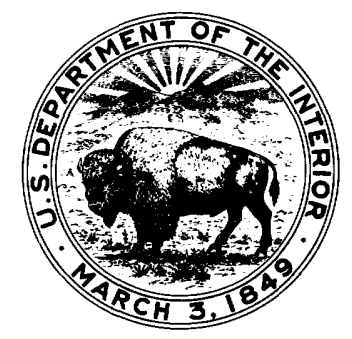




\section{UNITED STATES DEPARTMENT OF THE INTERIOR}

ROGERS C. B. MORTON, Secretary

\section{GEOLOGICAL SURVEY}

V. E. McKelvey, Director

Library of Congress catalog-card No. 73-600056

For sale by the Superintendent of Documents, U.S. Government Printing Office

Washington, D.C. 20402

Stock No. 2401-00299 


\section{CONTENTS}

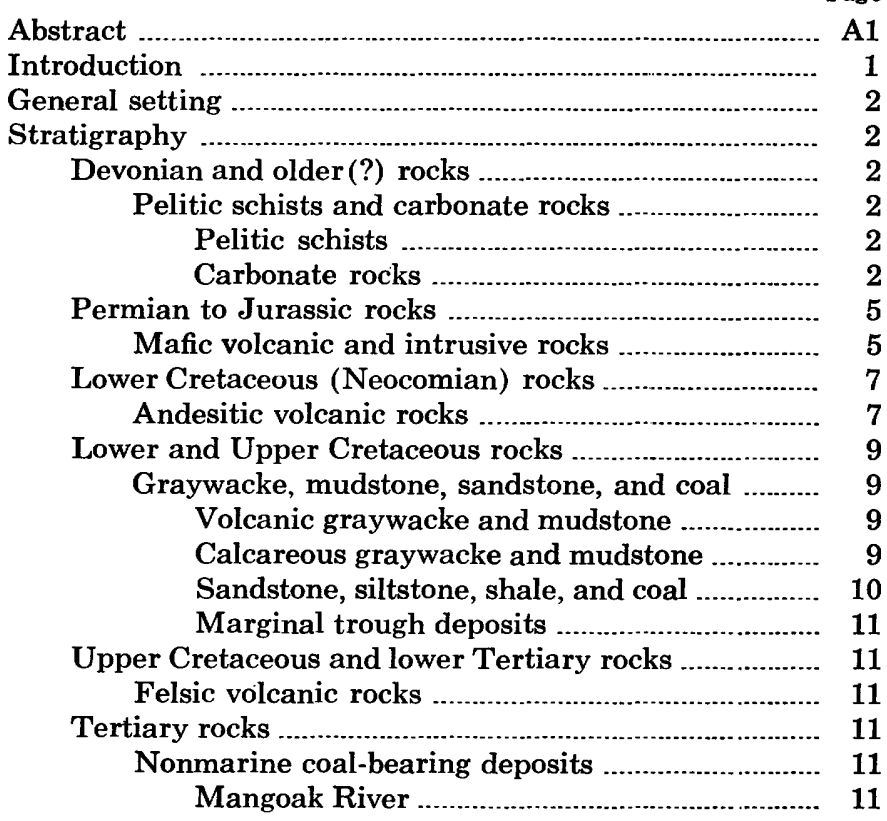

Stratigraphy-Continued

Tertiary rocks-Continued

Nonmarine coal-bearing deposits-Continued Elephant Point

A11

Norton Sound

Upper Tertiary (?) and Quaternary rocks .................... 11

Basalt ........................................................ 11

Intrusive rocks ................................................................ 12

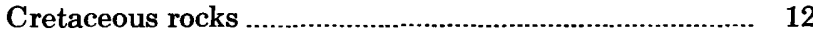

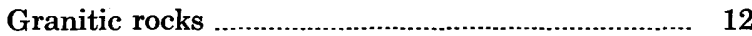

Structure ........................................................................ 12

Mid-Cretaceous basins .................................................. 12

Cenozoic basins ........................................................... 13

Kobuk-Selawik Lowlands ....................................... 14

Koyukuk Flats ........................................................ 14

Mesozoic and early Cenozoic structural trends ............ 14

Brooks Range trends ............................................ 14

Lisburne-Seward trends........................................... 14

Yukon trends ...................................................... 15

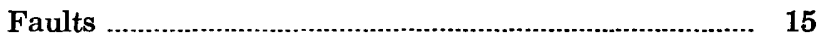

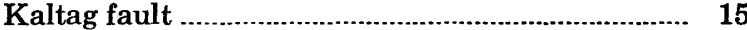

Kobuk fault zone ....................................................... 16

References cited .................................................................... 16

\section{ILLUSTRATIONS}

Page

2. Reconnaissance geologic map of northern Yukon-Koyukuk province ...............................................................

3. Map showing major structural features in northern Yukon-Koyukuk province ................................................... 4

4. Characteristic aeromagnetic profiles and diagrammatic cross section across northern Yukon-Koyukuk province .. 5

5. Correlation chart of Mesozoic and Cenozoic rocks in northern Yukon-Koyukuk province and Colville basin ........ 6

6. Chart showing major stratigraphic units in northern Yukon-Koyukuk province and its borderlands ...................... 7

7. Map showing Cretaceous depositional basins and present-day distribution of major stratigraphic units in northern Yukon-Koyukuk province

.

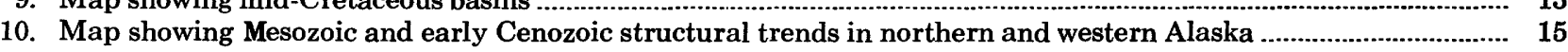





\title{
RECONNAISSANCE GEOLOGY OF THE NORTHERN YUKON-KOYUKUK PROVINCE, ALASKA
}

\author{
By William W. Patton, JR.
}

\section{ABSTRACT}

The northern part of the Yukon-Koyukuk province is a broad wedge-shaped depression of Cretaceous and Tertiary volcanic and sedimentary rocks bordered on the west, north, and southeast by a metamorphic complex, chiefly of Paleozoic age. The province is not a simple sedimentary basin, as formerly believed, but a highly mobile tract subjected to repeated volcanism and plutonism during Cretaceous and Tertiary times. The oldest rocks in the province are a thick sequence of marine andesitic volcanic rocks of earliest Cretaceous (Neocomian) age. These are overlain by terrigenous sedimentary rocks, largely of Early and Late Cretaceous (Albian and Cenomanian) age, which were deposited in two deep troughs separated by a broad volcanic and plutonic high. The sedimentary sequence, which locally may be as much as 25,000 feet thick, is made up chiefly of marine volcanic graywacke and mudstone but includes coalbearing paralic deposits in the upper part. Subaerial felsic volcanic rocks of Late Cretaceous and early Tertiary age are widespread in the eastern part of the province, and two broad basalt lava fields of late Cenozoic age occur in the western part of the province.

Three structural trends are recognizable among the intensely deformed rocks of the northern Yukon-Koyukuk province and its borderlands: East-west along the northern margin and in the adjoining Brooks Range, north-south in the western part of the province and on the Seward Peninsula, and northeastsouthwest along the Yukon and Koyukuk valleys. The province is transected between Ruby and Unalakleet by the Kaltag fault, a major strike-slip fault with $40-80$ miles of probable rightlateral offset. Major structural discontinuities occur along the Kobuk fault zone at the northern edge of the province, but evidence for large-scale strike-slip displacement is inconclusive.

\section{INTRODUCTION}

The Yukon-Koyukuk province is a broad tract of Cretaceous and Tertiary rocks that stretches across west-central and southwestern Alaska from the Brooks Range to the Yukon River delta (fig. 1). This vast region, covering more than one-sixth the total land area of Alaska, has been classed as a possible petroleum province (Miller and others, 1959) and is of continuing interest in the search for new sources of oil and gas.

This report is concerned with the northern part of the province, where, since 1958, the U.S. Geological
Survey has been conducting a program of reconnaissance-scale geologic mapping (fig.1). Much of the area has now been visited either by helicopter or riverboat, and, although information is still sketchy in many places, the broad outlines of the surface geology are known. Subsurface data, however, are limited to a small number of reconnaissance aeromagnetic profiles flown across the province by the U.S. Geological Survey and the records of a single 12,000-foot test well near Nulato on the Yukon River drilled by Paul Benedum and Associates in 1960.

Many colleagues in the U.S. Geological Survey have contributed to the mapping program in the northern Yukon-Koyukuk province since its inception in 1958, in particular, T. P. Miller, 1963-70, A. R. Tagg, 1959-

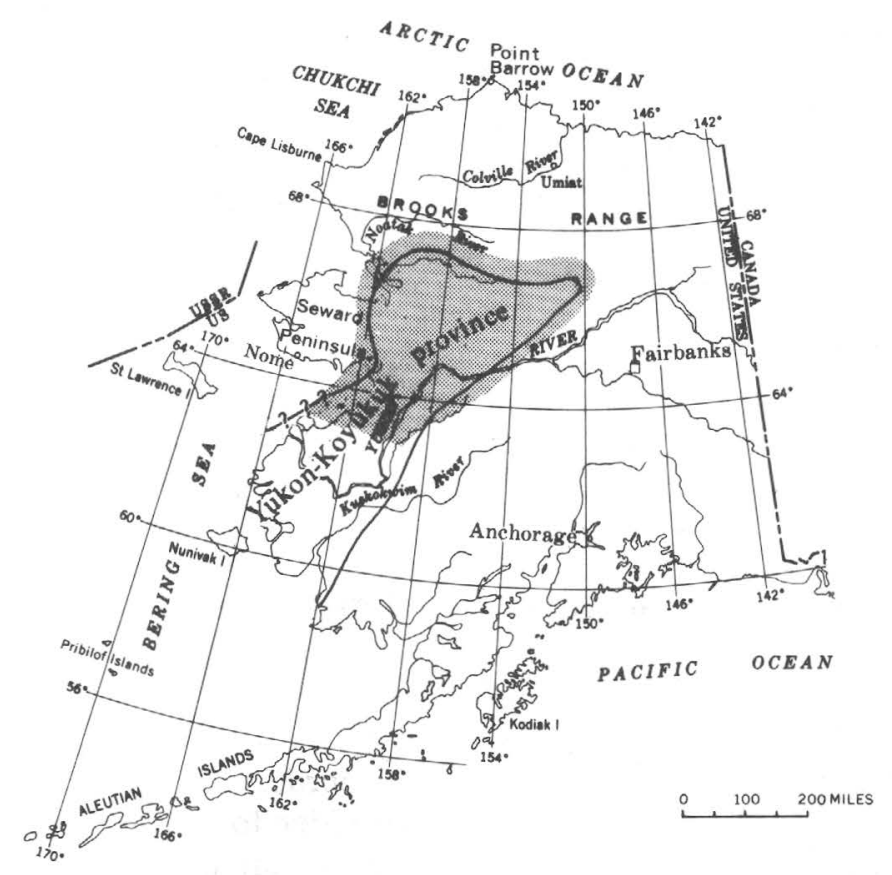

FIGURE 1.-Index map of Alaska, showing outline of YukonKoyukuk province and report area (shaded). 
1963, and J. M. Hoare, I. L. Tailleur, and Bond Taber, 1958.

\section{GENERAL SETTING}

The rocks of the northern Yukon-Koyukuk province are composed chiefly of volcanogenic sedimentary and andesitic volcanic rocks of Early and early Late Cretaceous age (figs. 2, 3, 4, and 7). Locally this assemblage is overlain by Late Cretaceous and Cenozoic subaerial volcanic rocks and intruded by Cretaceous granitic rocks. Bordering the province on three sides are narrow bands of mafic volcanic and intrusive rocks of late Paleozoic or early Mesozoic age and broad crystalline complexes of schist and carbonate rocks of Paleozoic and possibly Precambrian age.

Early workers (Payne, 1955; Miller and others, 1959) envisaged the Yukon-Koyukuk province as a simple Mesozoic and Cenozoic sedimentary basin or "geosyncline" comparable in tectonic history and style to the Colville basin on the Arctic Slope. However, as mapping of the Yukon-Koyukuk province has progressed, it has become apparent that these two broad structural depressions differ markedly (fig. 5). The Colville basin developed as a single large sedimentary trough steadily filled through most of Mesozoic and early Tertiary with detritus shed from the site of the present Brooks Range. The only igneous activity of consequence occurred in the Jurassic with the intrusion and extrusion of diabase and basalt along the disturbed belt of the western and central Arctic Foothills. In contrast, the Yukon-Koyukuk province was a highly mobile tract subjected to repeated volcanism through Mesozoic and Cenozoic times and to widespread plutonism in the Cretaceous. Sedimentation, though locally voluminous, was confined for the most part to a single short cataclysmic episode in mid-Cretaceous (Albian and Cenomanian) time. The sediments were not deposited in a single large basin covering the entire province but rather were distributed in smaller troughs that were separated by tectonically and volcanically active highs. Most of these sediments are composed of first- and second-cycle volcanic debris derived from these highs and from volcanic terranes that rim the province.

The mapping suggests that the Yukon-Koyukuk province is more aptly described as a volcanic or volcanogenic province rather than a sedimentary basin.

\section{STRATIGRAPHY}

The major stratigraphic units exposed in the northern Yukon-Koyukuk province and its borderlands range in age from Devonian and possibly older to Quaternary (fig. 6). Formal stratigraphic names were used locally for several of these units by earlier workers (fig. 6), but as none of these names seem to have provincewide application, they are not employed in this report.

\section{DEVONIAN AND OLDER (?) ROCKS PELITIC SCHISTS AND CARBONATE ROCKS}

A broad crystalline complex made up largely of metasedimentary rocks borders the northern YukonKoyukuk province on three sides. These metasedimentary rocks, chiefly pelitic schist and carbonate rocks, are widely exposed in the southern Brooks Range, Kokrines-Hodzana Highlands, and Kaiyuh Mountains, and on the eastern Seward Peninsula (fig. 2). Scattered exposures along the southeast shore of Kotzebue Sound suggest that they may also extend from the Seward Peninsula northward beneath Kotzebue Sound and the Kobuk-Selawik Lowlands to connect with similar metamorphic rocks at the southwest end of the Brooks Range. The metasedimentary rocks may also underlie the eastern part of Norton Sound, as indicated by their presence at the tip of Cape Denbigh and by their characteristic signature on magnetic profiles that cross the Sound (Scholl and Hopkins, 1969, p. 2076; King, 1961, p. 725). The metasedimentary rocks do not crop out south of the Kaltag fault on the west side of the province but may lie buried beneath the surficial deposits of the Yukon delta.

\section{PELITIC SCHISTS}

Most of the metasedimentary rocks are pelitic schists including quartz-mica schist, mica schist, phyllite, semischist, and fine-grained quartzite with local intercalations of calc schist, quartzo-feldspathic schist, and greenschist. In the Kokrines-Hodzana Highlands the schists are extensively intruded by Cretaceous granitic rocks and widely altered to andalusite-cordierite hornfels. All the schists are pervasively intruded by small bodies of altered diabase and gabbro of late Paleozoic or early Mesozoic age.

Because schists have not been studied in detail anywhere around the perimeter of the Yukon-Koyukuk province, their stratigraphy and internal structure are poorly understood. Some schists are clearly interlayered or interfingered with carbonate rocks and can be dated as mid-Paleozoic on fossil evidence (Patton and others, 1968). But in most places the stratigraphic relations are unclear, and there is no evidence upon which to base an age assignment. Whole-rock $\mathrm{Rb}-\mathrm{Sr}$ dates of $700 \mathrm{~m} . \mathrm{y}$. (million years) that were obtained by Sainsbury and others (1970) from possibly correlative metamorphic rocks on the central Seward Peninsula suggest that some of these schists may be as old as Precambrian.

\section{CARBONATE ROCKS}

Limestone and dolomite in massive sections as much as several thousand feet thick are widely exposed in 


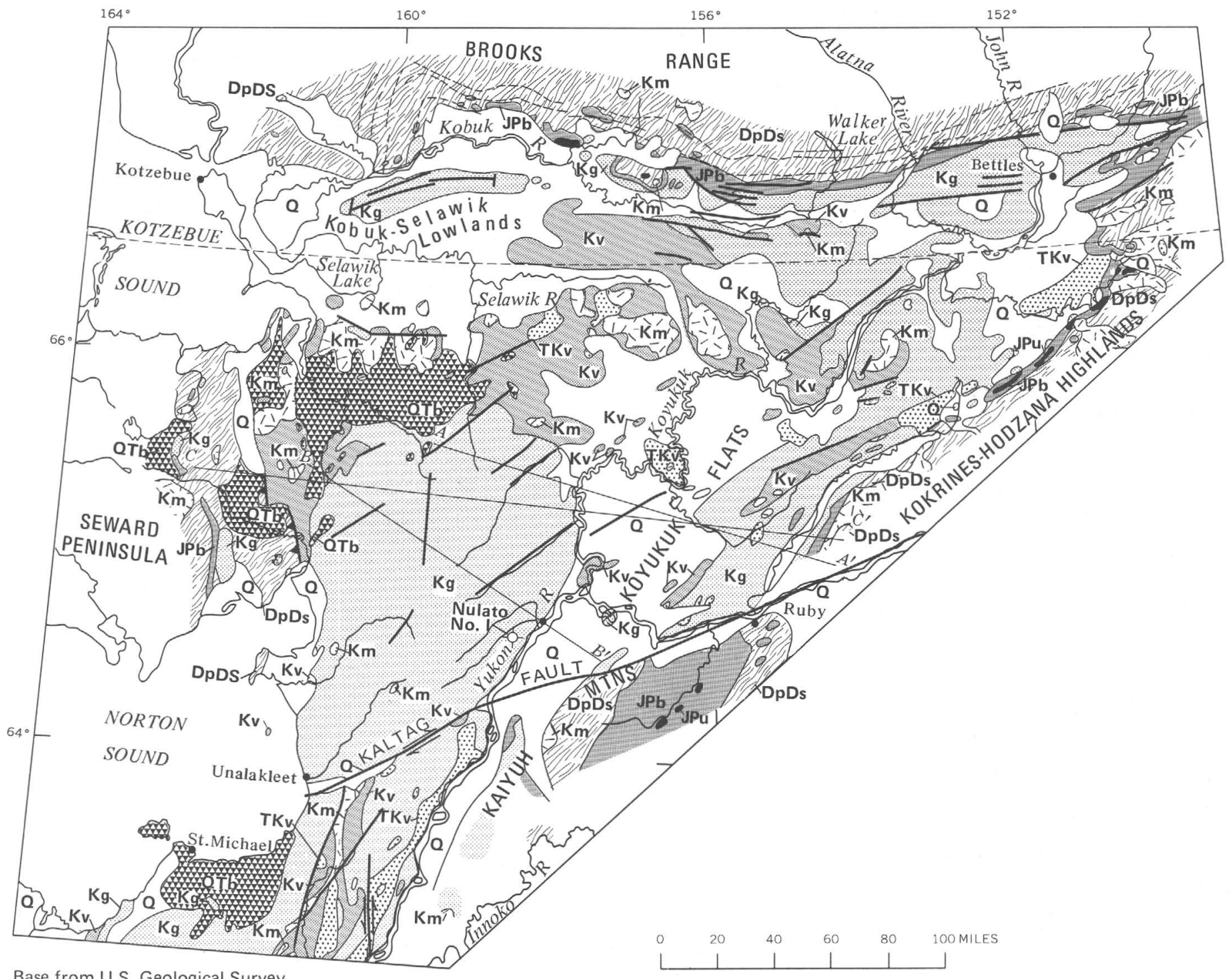

Base from U.S. Geological Survey 1:2,500,000, 1954

EXPLANATION

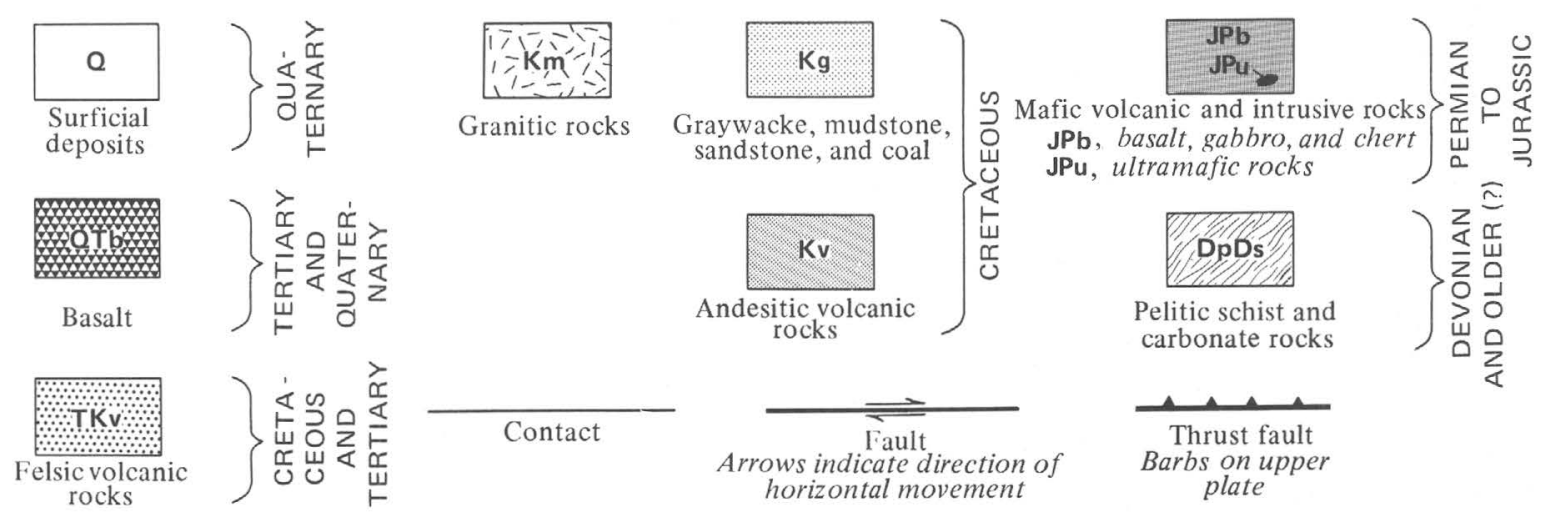

FIGURE 2.-Reconnaissance geologic map of northern Yukon-Koyukuk province. Sections are shown in figure 4. 


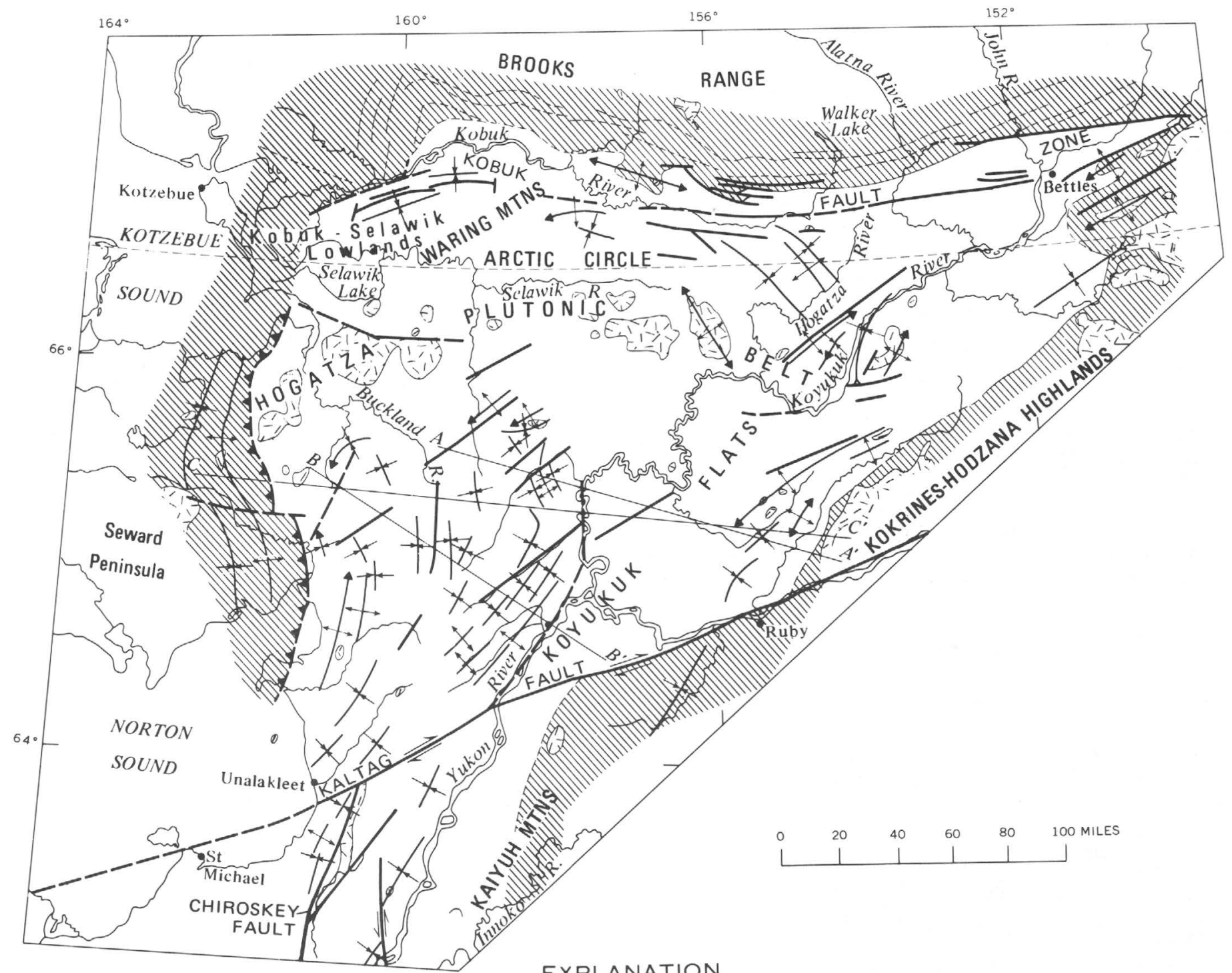

Base from U.S. Geological Survey $1: 2,500,000,1954$
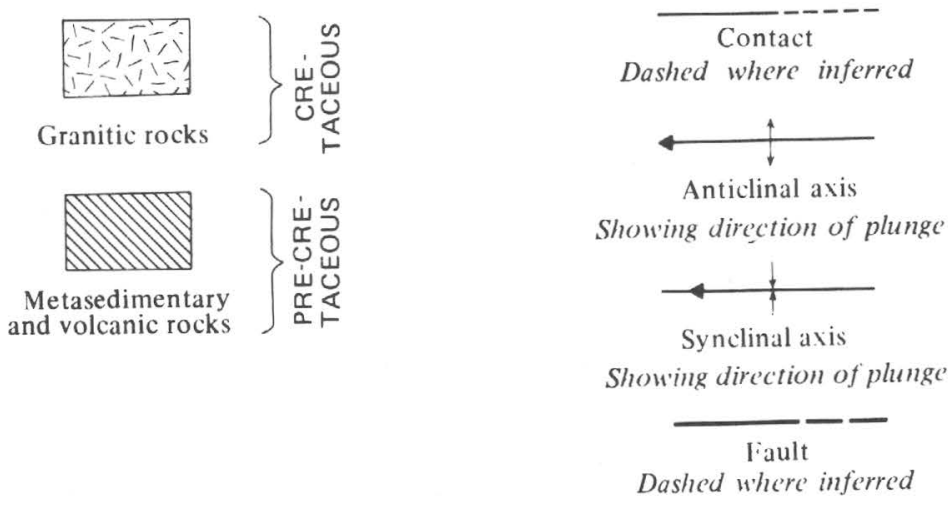

Strike - slip fault Arrows show direction of horizontal movement. Dashed where inferred

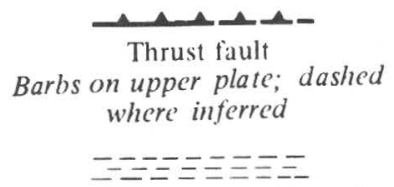

Trends in metamorphic rocks of Brooks Range

Dashed where inferred

FIGURE 3.-Major structural features in northern Yukon-Koyukuk province. Sections are shown in figure 4.

the Brooks Range and Kaiyuh Mountains and on the Seward Peninsula. These rocks are everywhere intensely deformed, and in many places are completely recrystallized to coarse marbles. Contacts between the car- bonate rocks and the pelitic schists are generally faulted, and many of the carbonate masses may be allochthonous. Evidence for large-scale thrusting of the carbonates has been found in the western Brooks 


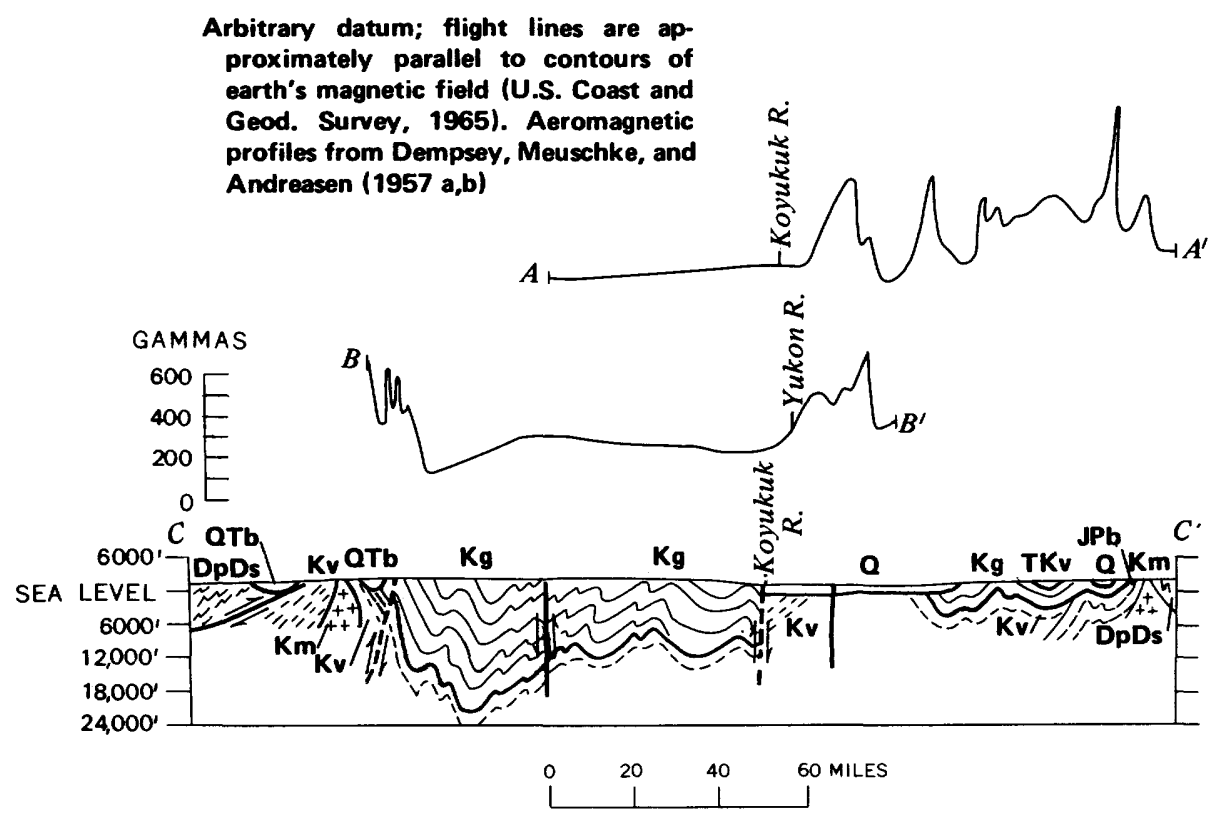

FIGURE 4.-Characteristic aeromagnetic profiles $\left(A-A^{\prime}, B-B^{\prime}\right)$ and diagrammatic cross section $\left(C-C^{\prime}\right)$ across northern Yukon-Koyukuk province. (See figs. 2 and 3 for location of profile and section lines and for explanation of letter symbols. Inferred faults not shown in figure 2.)

Range (Tailleur and others, 1967) and on the Seward Peninsula (Sainsbury, 1969).

The carbonate rocks appear to be chiefly Devonian in age but locally may include rocks as old as Silurian and Ordovician. Small collections of corals and mollusks of Devonian and possibly Silurian age have been reported from several areas bordering the northern Yukon-Koyukuk province, including the eastern Seward Peninsula (Smith and Eakin, 1911, p. 47-50), the southern Brooks Range (Patton and others, 1968), and the northern Kuskokwim Mountains (Mertie and Harrington, 1924, p. 21).

\section{PERMIAN TO JURASSIC ROCKS}

\section{MAFIC VOLCANIC AND INTRUSIVE ROCKS}

Mafic volcanic and intrusive rocks of late Paleozoic and possibly early Mesozoic age are extensively exposed along the margins of the Yukon-Koyukuk province; they form a narrow band that can be traced for more than 500 miles along the northern and southeastern border of the province. The rocks are widely distributed as small intrusive bodies within the adjoining metamorphic terrane (fig. 2). In the Kaiyuh Mountains the mafic rocks lie in a broad syncline flanked on the east and west by metamorphic rocks. The unit, which appears to constitute a typical ophiolite suite (Steinmann, 1926), is composed of pillow basalt, diabase, gabbro, radiolarian chert, serpentinized periodotite and dunite, and slate. All the volcanic and intrusive rocks are altered, in various degrees, to a characteristic "greenstone" mineral assemblage of chlorite, epidote, and sodic plagioclase; locally some of the fine-grained volcanic rocks have a faint foliation. The ultramafic rocks occur in bodies ranging in size from tiny fault blocks a few feet across to huge tabular masses covering as much as 20 square miles in area (Patton and Miller, 1970). Only the largest of these ultramafic bodies are shown on the geologic map (fig. 2).

The mafic volcanic and intrusive rocks clearly are older than the Cretaceous sedimentary and volcanic rocks and probably are younger than the Devonian and older(?) metamorphic rocks, which they locally appear to intrude. In various places around the rim of the province, the mafic rocks have been assigned provisional ages ranging from Devonian to Jurassic (Eakin, 1916; Patton and Miller, 1966, 1970; Fritts, 1970). However, none of the evidence for these assignments is completely convincing. To date the only firm evidence for an age is a single collection of Permian fossils (B. L. Mamet, oral commun., 1970; J. T. Dutro, Jr., oral commun., 1971) discovered in 1970 in a sequence of mafic volcanic rocks near Bettles (Patton and Miller, in U.S. Geological Survey, 1971).

Elsewhere in northern and western Alaska, similar assemblages of mafic rocks have yielded potassiumargon and fossil ages ranging from Permian to Jurassic. Tailleur (1970) reported a Jurassic potassium-argon age from mafic rocks in the western part of the Brooks Range. In the northern part of the range, Jurassic fossils have been recovered from an assemblage of mafic 


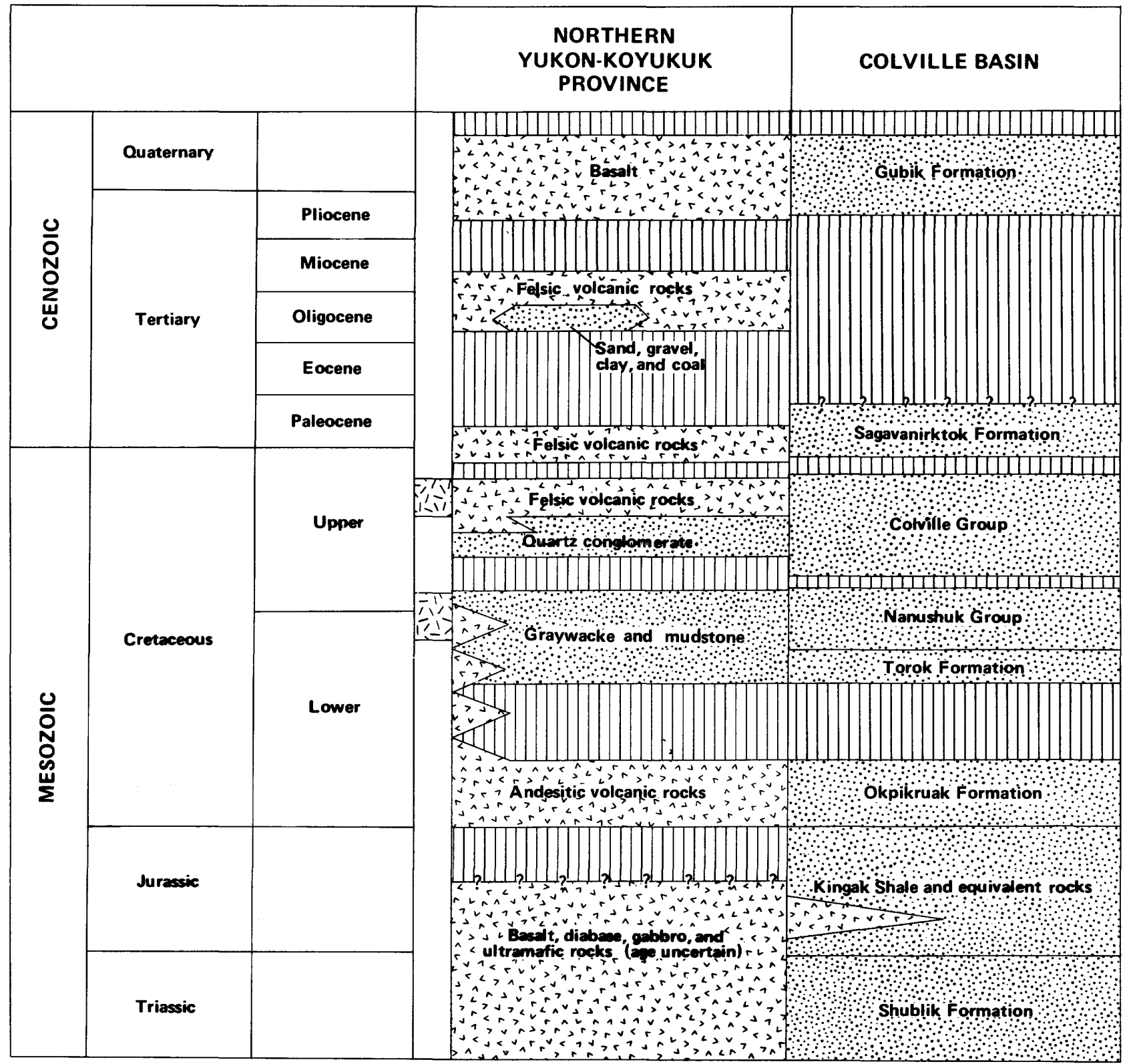

\section{EXPLANATION}
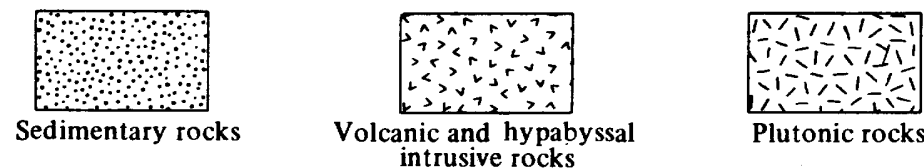

FiguRE 5.-Correlation of Mesozoic and Cenozoic rocks in northern Yukon-Koyukuk province and Colville basin.

volcanic rocks and radiolarian cherts (Patton and Tailleur, 1964, p. 481). In the Yukon River valley, about 50 miles southeast of the province, mafic volcanic rocks belonging to the Rampart Group have been dated by fossils as probably Permian, and gabbro that intrudes the volcanic rocks has been dated by the potassiumargon method as Triassic (Brosgé and others, 1969).
The weight of evidence suggests that the mafic volcanic and intrusive rocks of the Yukon-Koyukuk province are late Paleozoic (Permian) and possibly early Mesozoic (Triassic and Jurassic) in age. The fossilbearing volcanic rocks near Bettles can be dated as Permian, but until additional evidence is found, it would seem unwise to conclude that all the diverse rock 


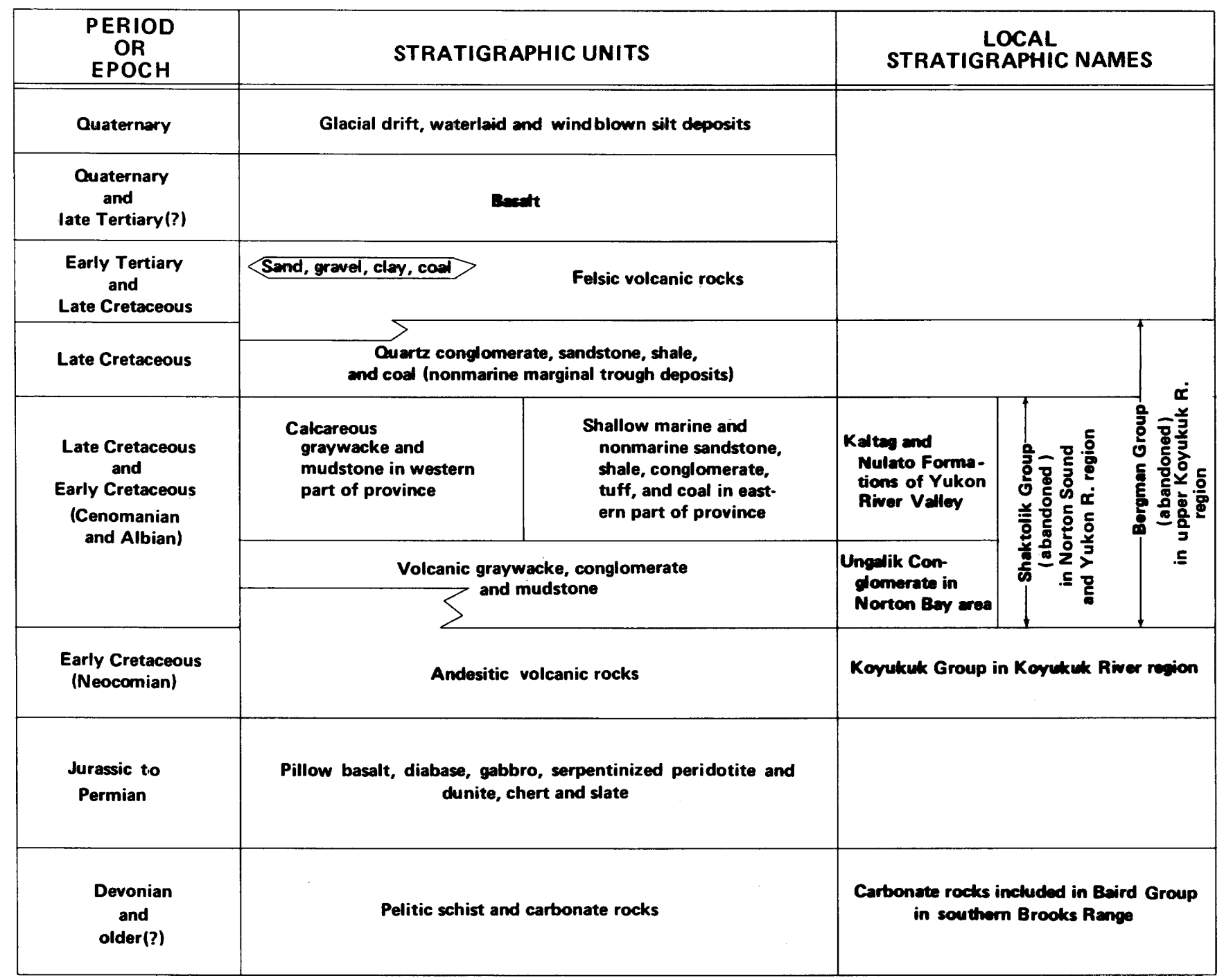

FIGURE 6.-Major stratigraphic units in northern Yukon-Koyukuk province and its borderlands.

types which compose this ophiolitelike assemblage are exactly the same age.

\section{LOWER CRETACEOUS (NEOCOMIAN) ROCKS ANDESITIC VOLCANIC ROCKS}

The base of the Cretaceous sequence in the northern Yukon-Koyukuk province is made up of marine andesitic volcanic rocks that appear to underlie nearly the entire province (fig. 7 ). The andesitic rocks are widely exposed on a broad uplift that extends eastward across the province from the Seward Peninsula and Kotzebue Sound to the Koyukuk valley (fig. 2). Aeromagnetic profiles suggest that they also underlie large parts of the Koyukuk Flats and Kobuk-Selawik Lowlands (Zietz and others, 1959; Patton and Miller, 1968; Patton and others, 1968). In the Koyukuk River region these andesitic rocks have been referred to the Koyukuk Group (Schrader, 1904; Smith, 1913; Martin, 1926; Imlay and Reeside, 1954) (fig. 6).

The andesitic volcanic assemblage is composed predominantly of volcaniclastic rocks, but it also contains porphyritic pyroxene andesite flows and hypabyssal rocks. The volcaniclastic rocks include crystal and lithic tuffs, massive breccias, agglomerates and conglomerates, and tuffaceous graywacke and mudstone. Lenticular masses as much as 300 feet thick of shelly limestone with abundant Buchia are intercalated in the volcanic sequence in the upper Koyukuk and Kobuk valleys. Along the Hogatza plutonic belt (fig. 3 ), broad areas of volcanic rocks have been propylitically altered to a uniformily hard pale-green hornfels composed largely of chlorite, epidote, calcite, and sodic plagioclase. 

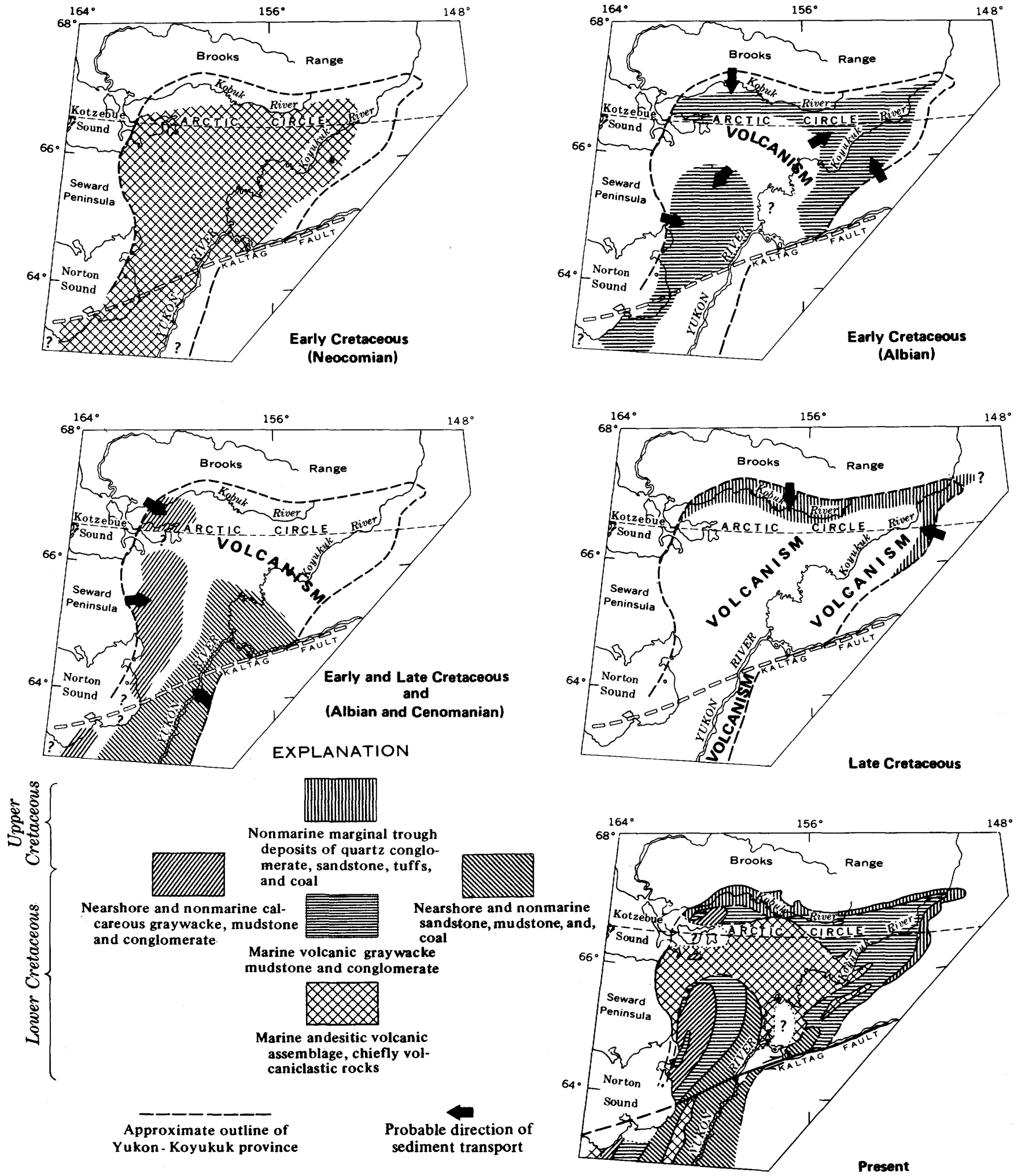

$50 \quad 100 \quad 150$ MILES

FIGURE 7.-Cretaceous depositional basins and present-day distribution of major stratigraphic units in northern YukonKoyukuk province. Cretaceous depositional basins not palinspastically restored for offset along Kaltag fault. 
The total thickness of the andesitic volcanic rocks is not known because the base of the assemblage is not exposed. Along the northern and southeastern margins of the province, the volcanic rocks are overlapped by clastic sedimentary deposits of late Early and Late Cretaceous age; and on the Seward Peninsula at the western margin of the province, the volcanic rocks appear to be in thrust-fault contact with metasedimentary rocks of Paleozoic and older age. An estimated 5,000 feet of andesitic volcanic rocks is exposed along the Koyukuk River below Hughes, but the full thickness of the assembage may be several times this.

Marine fossils have been found in the andesitic volcanic rocks at 25 widely scattered localities in the northern Yukon-Koyukuk province. Earliest Cretaceous (Neocomian) species of Buchia are common to nearly all the collections. Five potassium-argon dates obtained from flows and hypabyssal intrusives also have yielded Early Cretaceous ages ranging from $134 \pm 5$ m.y. to $117 \pm 4.3$ m.y. (Patton and Miller, 1966; Patton, 1967; Patton and others, 1968; Geol. Soc. London, 1964).

Although most of the andesitic volcanic rocks are earliest Cretaceous (Neocomian) in age, the unit locally includes some younger crystal and lithic tuff beds that seem to be laterally gradational with sedimentary rocks of mid-Cretaceous (Albian and Cenomanian) age.

\section{LOWER AND UPPER CRETACEOUS ROCKS}

\section{GRAYWACKE, MUDSTONE, SANDSTONE, AND COAL}

Terrigenous sedimentary rocks of Cretaceous age underlie about half of the northern Yukon-Koyukuk province (fig. 2). Most of these rocks were deposited during a relatively short interval in mid-Cretaceous (Albian and Cenomanian) time and are characterized throughout the province by wide variations in thickness and lithology. Owing to their "poured in" nature and lack of sorting, these strata are not amenable to rigorous stratigraphic treatment and classification. Earlier workers referred these beds to the Bergman Group (Schrader, 1904; Martin, 1926; Imlay and Reeside, 1954) in the upper Koyukuk-Kobuk region and to the Shaktolik Group (Smith and Eakin, 1911; Martin, 1926; Imlay and Reeside, 1954) in the Yukon RiverNorton Sound region (fig. 6). However, the lithologic character and areal limits of the two groups as presently defined are so vague and generalized that the names appear to have little practical value and are hereby abandoned.

In this report the Cretaceous sedimentary rocks are subdivided into four lithologic units which, though broadly gradational, can be mapped in a gross way.
Probable areas of deposition and present-day distribution of these units are shown in figure 7.

\section{VOLCANIC GRAYWACKE AND MUDSTONE}

Marine turbidites, chiefly volcanic graywacke and mudstone, accumulated in enormous thicknesses during late Early Cretaceous (Albian) time. These rocks are widely distributed in the northeastern part of the province and along the drainage divide between the Yukon River and Norton Sound. The turbidites appear to have been deposited in two basins that were separated by a broad arcuate high of Neocomian andesitic volcanic rocks extending from Kotzebue Sound and the Seward Peninsula to the Koyukuk River valley (fig. 7). Typically these rocks form a monotonously uniform, rhythmically interbedded succession with few distinctive horizon markers. At the margins of the province they contain masses of polymict conglomerate as much as 5,000 feet thick, and along the borders of the volcanic high they are intercalated with crystal and lithic tuffs. Field and aeromagnetic data suggest that these volcanic graywacke and mudstone beds have an aggregate thickness of more than 20,000 feet along the Yukon River-Norton Sound divide (Gates and others, 1968).

Modal grain counts show that the volcanic graywackes are composed, on the average, of about 40 percent volcanic rock fragments and feldspar (chiefly plagioclase), 35 percent argillaceous matrix, and less than 10 percent quartz (Patton and Miller, 1966; Patton, 1967). The volcanic debris appears to have been derived in part from the late Paleozoic and early Mesozoic mafic volcanic rocks that rim the province, and in part from earliest Cretaceous andesitic volcanic rocks within the province (fig. 7).

Fossils in the volcanic graywacke and mudstone unit are confined, for the most part, to isolated occurrences of ammonites. Collections from 18 separate localities in the northern part of the province include Grantziceras, Lemuroceras, Cleoniceras, Beudanticeras, Arcthoplites, and Gastroplites, which date these rocks as late Early Cretaceous (Albian).

\section{CALCAREOUS GRAYWACKE AND MUDSTONE}

In the western part of the province the volcanic graywacke and mudstone turbidites are overlain gradationally by an assemblage of shallow-water calcareous graywacke and mudstone, possibly as much as 5,000 feet thick. These calcareous strata appear to have been deposited in a broad trough that extended along the western margin of the province from the Kobuk River to beyond the south edge of the report area (fig. 7). The strata coarsen westward across the trough and at the west edge of the province grade into nonmarine 
conglomeratic coal-bearing deposits that lap onto the adjoining volcanic and metamorphic terrane. Several small outlying masses of the coal-bearing deposits are preserved in local structural depressions within the metamorphic terrane of the eastern Seward Peninsula (fig. 2).

The calcareous graywacke and mudstone are composed of from 30-80 percent carbonate (Patton, 1967; Patton and Miller, 1968), much of which appears to be detrital and derived from Paleozoic limestone and dolomite of the Seward Peninsula and western Brooks Range (fig. 7). Massive pebble-cobble conglomerates made up almost entirely of limestone and dolomite clasts occur along the west edge of the province on the Seward Peninsula and in the Waring Mountains.

The calcareous graywacke and mudstone assemblage is tentatively assigned a late Early and an early Late Cretaceous age. Fossils in these strata are notably scarce, but several small collections of shallow-water mollusks of probable late Early Cretaceous (Albian) age have been found in the lower part of the unit in the Waring Mountains (Patton and Miller, 1968), and samples collected from the coal-bearing facies on the Seward Peninsula have yielded pollen of both Early and Late Cretaceous ages (E. B. Leopold, written commun., 1963). In the Waring Mountains, this assemblage is overlain by nonmarine marginal trough deposits which have been dated by potassium-argon methods at 84 m.y. (Patton and Miller, 1968).

\section{SANDSTONE, SILTSTONE, SHALE, AND COAL}

In the southeastern part of the province, the volcanic graywacke and mudstone unit is succeeded by shallow marine and nonmarine beds of sandstone, siltstone, shale, and coal which appear to be broadly correlative with the calcareous graywacke and mudstone unit (fig. 6). These coal-bearing beds, which have an aggregate thickness of at least 10,000 feet (Patton, 1966), consist of a regressive sequence that grades upward from marine shale and sandstone into nonmarine shale, siltstone, sandstone, and coal. Winnowed strand-line sandstone and quartz conglomerate occur locally in the zone of interfingering marine and nonmarine beds. This unit is generally distinguished from the other mid-Cretaceous sedimentary units by better sorting and by a higher percentage of quartz and other resistant rock and mineral detritus.

The coal-bearing beds appear to have been deposited in a broad shallow trough that extended along the eastern margin of the province from the north edge of the Koyukuk Flats to beyond the south edge of the report area (fig. 7). On the west they rest on volcanic graywacke and mudstone, but eastward they appear to overlap onto andesitic volcanic rocks. The probable source of these deposits was the metamorphic terrane in the Kaiyuh Mountains and Kokrines-Hodzana Highlands bordering the southeastern margin of the province (figs. 2 and 7). Some ash-fall tuffs were intercalated with the deposits at the north end of the depositional trough, presumably derived from the broad volcanic complex that lay to the north.

The exposures of this coal-bearing sequence along the Yukon River have been described in detail by several workers (Martin, 1926; Hollick, 1930; Patton and Bickel, 1956a). Martin (1926, p. 400) assigned the marine beds in the lower part of the sequence to the Nulato Formation and the nonmarine beds in the upper part to the Kaltag Formation (fig. 6). He described a third unit, the Melozi Formation, which he supposed represented a nonmarine tongue beneath the Nulato but which more recent evidence (Patton and Bickel, 1956a; Bell, 1963, p. 10) suggests is a marginal facies of the Kaltag. Owing to wide variations in lithology and poor exposure, it has not been possible to map the Nulato and Kaltag Formations beyond their type areas.

The marine strata in the lower part of the sequence contain abundant shallow-water mollusks of late Early Cretaceous (Albian) age including Inoceramus altifluminus McLearn and Gastroplites kingi McLearn. The contact with the overlying nonmarine beds appears to be diachronous, however, for Turrilites acutus Passy of early Late Cretaceous (Cenomanian) age (D. L. Jones, written commun., 1968) was discovered recently in the upper part of the marine beds on the Anvik River near the south edge of the map area. The marine strata, including the Nulato Formation of the Yukon River area, must therefore be considered as both Early and Late Cretaceous in age rather than entirely Early Cretaceous as suggested by Imlay and Reeside (1954).

The nonmarine beds, including the Kaltag Formation, contain abundant plant fossils, but their exact age remains in dispute. Hollick (1930) first described the flora in detail and assigned these beds to the Late Cretaceous. Later, the age was revised by Imlay and Reeside (1954, p. 237) to late Early Cretaceous (Albian), chiefly on the basis of the close association of these beds with the mollusk-bearing marine beds of the Nulato Formation. Subsequently, however, this Early Cretaceous age assignment was questioned by Bell (1963), who pointed out the strong floral correlation between the Kaltag Formation and the Late Cretaceous (Cenomanian) Dunvegan Formation of western Canada. The recent discovery of the Cenomanian mollusk Turrilites acutus Passy in the underlying marine beds on the Anvik River seems to provide firm evidence that at least some of the plant-bearing beds included in this unit are Late Cretaceous in age. 


\section{MARGINAL TROUGH DEPOSITS}

A narrow band of nonmarine quartz conglomerate has been traced for nearly 450 miles along the northern and southeastern margin of the Yukon-Koyukuk province (fig. 7). Small patches of these conglomerates are found along northeast-trending faults in the vicinity of Hughes on the Koyukuk River. In addition to quartz conglomerate, these molasselike deposits contain minor amounts of quartz sandstone, shale, thin bituminous coal beds, and ash-fall tuffs. They rest uncomformably upon Albian and Cenomanian sedimentary deposits within the province and lap onto the pre-Cretaceous igneous and metamorphic rocks that rim the province. They appear to have accumulated in a narrow fault-bounded trench bordering a highland source terrane composed of Devonian and older metamorphic rocks (fig. 7). Along the lower Kobuk River, these deposits appear to be at least 3,000 feet thick (Patton and Miller, 1968).

Poorly preserved plant fossils of probable Cretaceous age have been collected from these deposits at several localities, and biotite from an interbedded ash-fall tuff has been dated by potassium-argon methods as 83.4 \pm 2.2 m.y. (middle Late Cretaceous) Patton and Miller, 1968).

\section{UPPER CRETACEOUS AND LOWER TERTIARY ROCKS}

\section{FELSIC VOLCANIC ROCKS}

Felsic extrusive and hypabyssal rocks, chiefly latites and rhyolites, are widespread in the eastern part of the province (fig. 2). Subaerial flows and tuffs, as much as 2,000 feet thick, occur in gently to moderately folded synclines that rest unconformably upon andesitic volcanic rocks of earliest Cretaceous age and upon sedimentary rocks of mid-Cretaceous age. Locally in the northeastern part of the province, these volcanics interfinger with marginal trough quartz conglomerate deposits of Late Cretaceous age. Swarms of small sills, dikes, and pluglike bodies of latite and rhyolite pervasively intrude older Cretaceous volcanic and sedimentary rocks along a 60-mile-wide belt bordering the southeastern margin of the province. Many of these hypabyssal bodies appear to be alined along northeasttrending faults.

The felsic volcanic rocks range in age from Late Cretaceous to early Tertiary. A potassium-argon age of 85 m.y. (Late Cretaceous) was obtained from a crystal tuff in the upper Selawik River region (Patton and others, 1968), and an age of 58 m.y. (early Tertiary) from a felsic flow in the Koyukuk River valley. A pollen flora of early Tertiary age (E. B. Leopold, written commun., 1966) was recovered from terrestrial sedi- ments interbedded with the volcanics on the Yukon River.

\section{TERTIARY ROCKS}

NONMARINE COAL-BEARING DEPOSITS

Small deposits of poorly consolidated nonmarine coal-bearing beds of Teritary age have been found at three widely scattered localities in the northern YukonKoyukuk province (fig. 8). All three deposits appear to be of limited extent and confined to small structural or topographic basins.

\section{MANGOAK RIVER}

Moderately dipping beds of gravel and sand are exposed in a 30-foot-high stream bluff on the Mangoak River at the south edge of the Kobuk-Selawik Lowlands (Patton and Miller, 1968). The deposits appear to lie in an east-trending fault zone along the north front of the Selawik Hills. Lignitic coal, found in float at the base of the bluff, contains an abundant Tertiary pollen flora (E. B. Leopold, written commun., 1970).

\section{ELEPHANT POINT}

A 2-foot seam of lignite in a beach bluff of silt near Elephant Point on Kotzebue Sound was reported by Quackenbush in 1909 . This locality was revisited by R. J. Janda and D. S. McCulloch (oral commun.) in 1961 and although the exposure of coal was not found, float of coal containing a pollen flora of early Tertiary age (E. B. Leopold, oral commun., 1963) was collected from the beach nearby.

\section{NORTON SOUND}

Clays containing lignitic coal were discovered in a badly slumped beach bluff 10 miles south of Unalakleet on the shore of Norton Sound. Samples of the coal yielded an abundant pollen flora of early Teritary age (E. B. Leopold, written commun., 1966).

\section{UPPER TERTIARY(?) AND QUATERNARY ROCKS}

\section{BASALT}

Nearly flat-lying flows of olivine basalt cover more than 2,000 square miles of the province in the Buckland River area southeast of Kotzebue Sound and along the south shore of Norton Sound near St. Michael. The basalt appears to have been extruded over a terrain of moderate relief and locally is as much as 500 feet thick. The flows are deeply incised by Holocene drainages and thickly mantled by late Pleistocene wind-blown silts and glacial drift. Most of the flows are believed to be early Pleistocene and probably Pliocene 


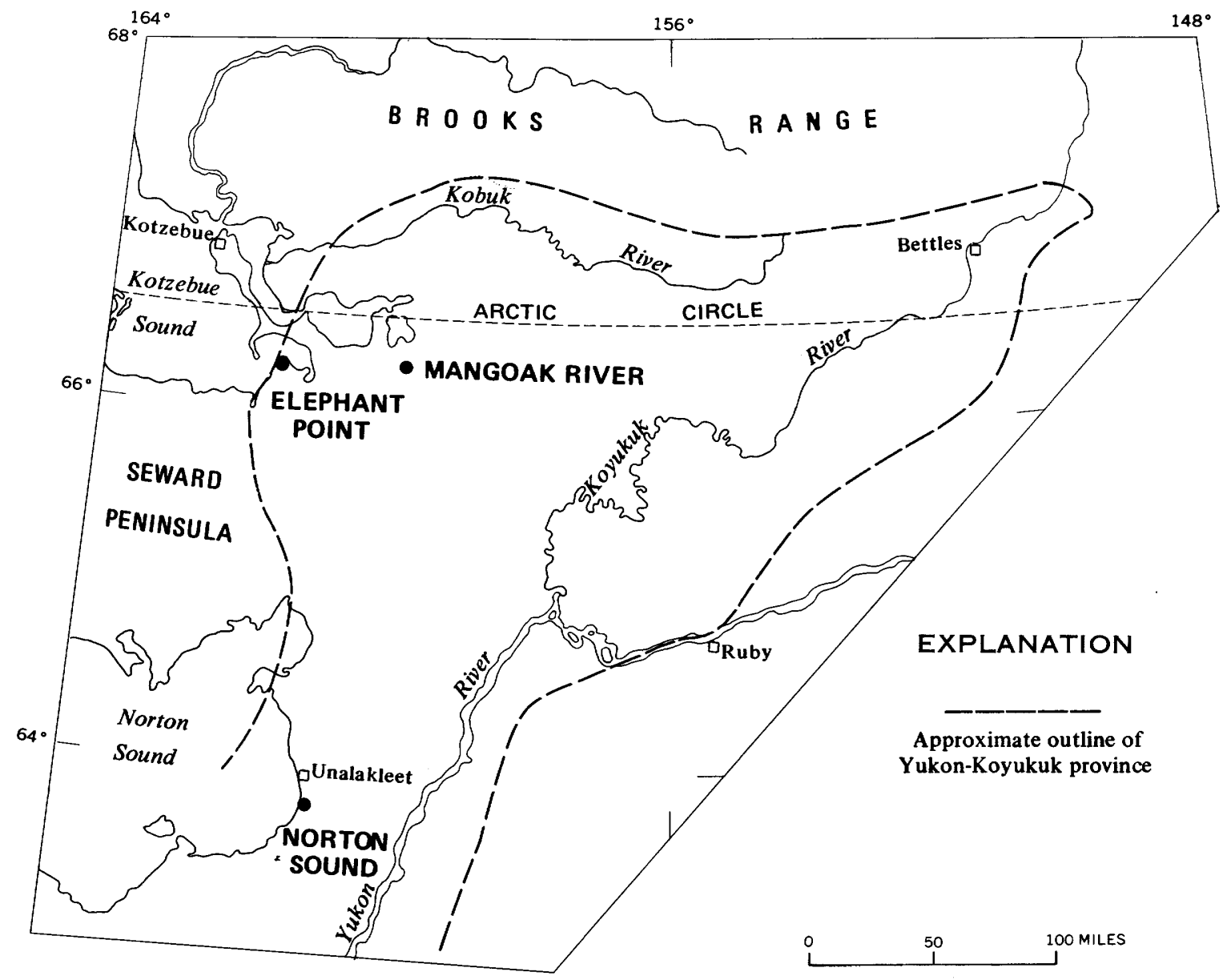

FIGURE 8.-Occurrences of Tertiary nonmarine coal-bearing deposits in northern Yukon-Koyukuk province.

in age, although some fresh unmodified cinder cones and flows that are clearly Holocene in age occur in both the Buckland River and St. Michaels areas.

\section{INTRUSIVE ROCKS CRETACEOUS ROCKS GRANITIC ROCKS}

The Hogatza belt of granitic plutons extends for a distance of 225 miles across the north-central part of the province from the Seward Peninsula to Koyukuk River valley (fig. 3 ). Sixteen separate plutons that range in area from 3 to 350 square miles have been mapped along this belt (Miller, 1970; Miller and others, 1966; Patton, 1967). The plutons, which have been dated by the potassium-argon method at 11 selected localities, can be divided into a syntectonic mid-Cretaceous $(\sim 100$ m.y.) suite in the western and central parts of the belt and a late tectonic or posttectonic Late Cretaceous $(\sim 80$ m.y.) suite in the eastern part. The mid-Cretaceous suite, composed of monzonite, syenite, quartz monzonite, and minor alkaline subsilicic rocks, intrudes earliest Cretaceous andesitic volcanic rocks and is stratigraphically bracketed by the Albian and Cenomanian sedimentary deposits. The Late Cretaceous suite, chiefly of quartz monzonite and granodiorite, intrudes both the andesitic volcanic rocks and the sedimentary rocks and appears to be related spatially and temporally to the Late Cretaceous terrestrial felsic volcanic rocks.

Intrusives of quartz monzonite and granodiorite are also widespread in the crystalline compex of the Kokrines-Hodzana Highlands. Two potassium-argon determinations from these plutons have yielded mid-Cretaceous ( $\sim 100$ m.y.) ages (Brosgé and Reiser, 1964).

\section{STRUCTURE}

\section{MID-CRETACEOUS BASINS}

The mid-Cretaceous sedimentary rocks occur in two vaguely defined structural depressions: the Lower Yukon basin, which extends in a broad band alcng the west edge of the province from the latitude of Kotzebue Sound southward to the Yukon delta, and the KobukKoyukuk basin, which occupies a V-shaped area along the northern and southeastern margins of the province 


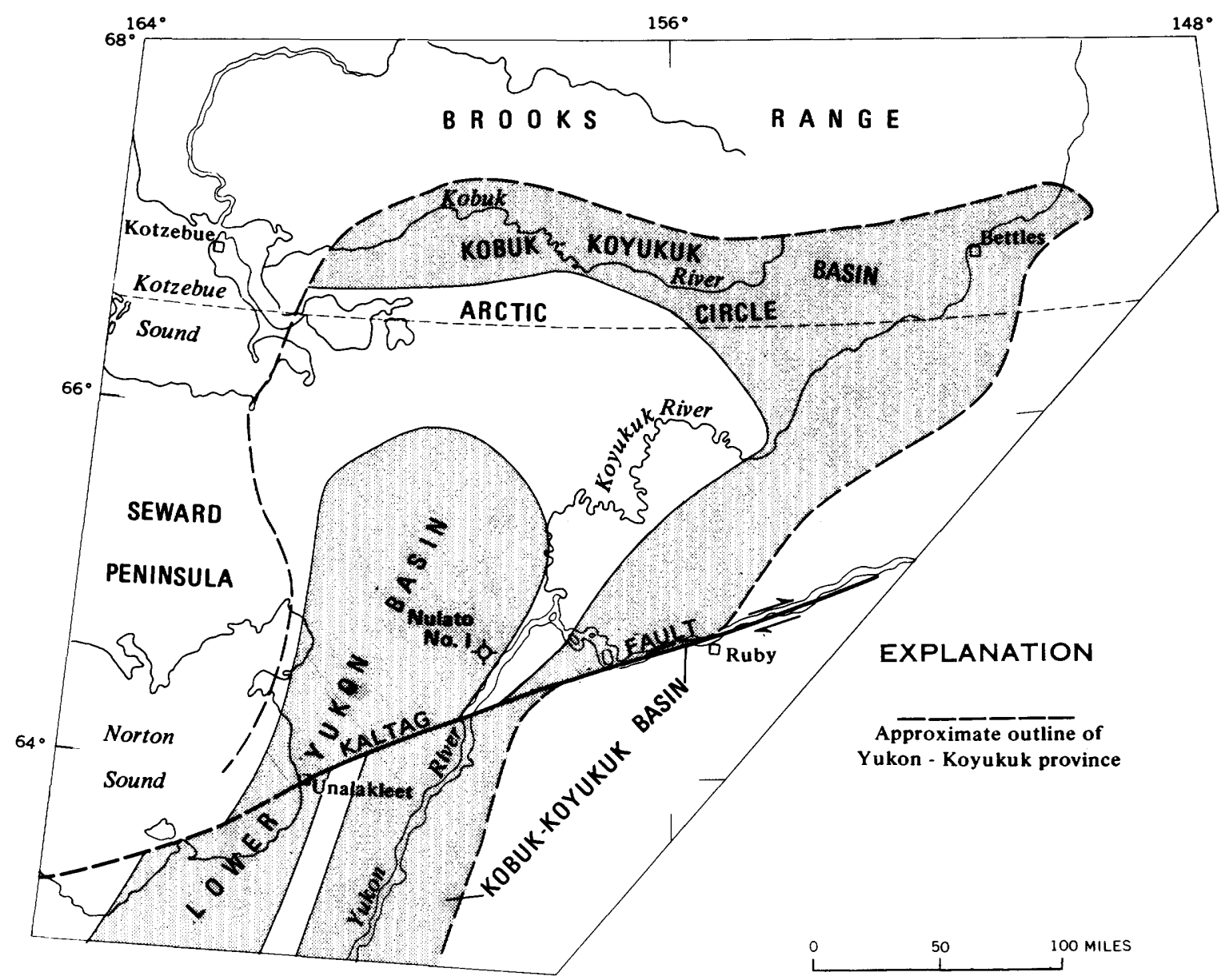

FiguRE 9.-Mid-Cretaceous basins.

(fig. 9). The two basins are separated by a broad structural high of Early Cretaceous volcanic rocks that trends eastward from Kotzebue Sound to the Koyukuk River and then southward beneath the Koyukuk Flats. Near the Kaltag fault, the high narrows and the basins converge. South of the Kaltag fault, the two basins appear to be offset to the southwest about 60-80 miles (fig. 9).

Aeromagnetic data indicate that the Lower Yukon basin may be 15,000-25,000 feet deep (Zietz and others, 1959). Magnetic profiles over the basin are characteristically smooth and free of large-amplitude anomalies suggesting that the underlying Early Cretaceous volcanic rocks probably are buried at great depth (fig. 4). Nulato No. 1, a stratigraphic test hole located on the east side of the basin, was drilled to a depth of 12,000 feet entirely in Cretaceous sedimentary rocks (fig. 9).

Few geophysical data are available for the V-shaped Kobuk-Koyukuk basin. Surface mapping suggests that the north limb may be filled with more than 10,000 feet of volcanic graywacke and mudstone and nonmarine marginal trough deposits. The sedimentary section along the southeast limb, however, seems to be substantially thinner, probably less than 5,000 feet thick. Aeromagnetic profiles that cross the southeast limb east of the Koyukuk Flats are typified by steep gradient and high-amplitude anomalies reflecting in part the thinness of the Cretaceous sequence and in part of the local occurrence of Late Cretaceous and early Tertiary felsic volcanic and hypabyssal rocks (fig. 4).

\section{CENOZOIC BASINS}

The northern Yukon-Koyukuk province includes two broad lowland areas, the Koyukuk Flats and the Kobuk-Selawik Lowlands, which are thickly blanketed by Quaternary silts and glacial deposits. Payne (1955) and Miller, Payne, Gryc (1959) have suggested that these two areas, as well as other large interior and coastal lowlands of central Alaska, may represent Cenozoic structural depressions that contain thick sections of Tertiary strata. The following assessment of the subsurface character of the Kobuk-Selawik Lowlands and Koyukuk Flats is based upon scattered aeromagnetic 
profiles across the lowlands and recent bedrock mapping around their margins.

\section{KOBUK-SELAWIK LOWLANDS}

It seems unlikely that Cretaceous or Tertiary sedimentary rocks are present in significant thicknesses beneath the Quaternary surficial deposits in the eastern part of the Kobuk-Selawik Lowlands. Intrusive and volcanic rocks crop out near the south edge of Selawik Lake, and aeromagnetic profiles along the north side of the lake show steep-gradient, large-amplitude anomalies which suggest that igneous rocks are at shallow depth (Andreasen, 1960; Dempsey and others, 1957c). Aeromagnetic profiles over the Kobuk River delta in the western part of the lowland are relatively smooth and free of marked magnetic anomalies (Miller and Anderson, 1969). This smoothness probably reflects the presence of a thick wedge of Quaternary fill beneath the delta, but the possibility that the delta and adjoining parts of Kotzebue Sound may also be underlain by Cretaceous or Tertiary sedimentary rocks cannot be ruled out. Recent marine geophysical surveys suggest that as much as $3 \mathrm{~km}$ of moderately deformed strata of Cenozoic and possibly Late Cretaceous age underlies large parts of the adjoining Chukchi Sea basin( Grantz and others, 1970).

\section{KOYUKUK FLATS}

Aeromagnetic profiles across the Koyukuk Flats, characterized by anomalies of large amplitude and steep gradient, indicate the presence of highly magnetic rocks at shallow depths (fig. 4). Surface mapping around the margin of the flats suggests that the Quaternary alluvial deposits are probably underlain by andesitic volcanic rocks of Early Cretaceous age (fig. 2). The flats do not appear to contain any substantial thickness of Cenozoic sedimentary strata, except along the Kaltag fault where evidence of recent sinking (Patton and Hoare, 1968) and a gravity low (Barnes, 1969) indicate the presence of a fault trench filled with late Cenozoic deposits.

\section{MESOZOIC AND EARLY CENOZOIC STRUCTURAL TRENDS}

All pre-Tertiary rocks in the northern Yukon-Koyukuk province are intensely deformed and are characterized by steep dips, tight folds, and closely spaced highangle faults. (See, for example, Patton and Bickel, 1956a, b; Bickel and Patton, 1957; Patton, 1966, 1967.) Some broad regional flexures are shown in figure 3, but it should be emphasized that these larger features are everywhere complicated by small, tightly appressed folds and innumerable small faults.

Fold and fault trends along the northern margin of the province roughly parallel the east-west grain of the Brooks Range. The broad structural high along the Hogatza plutonic belt also has a general east-west alinement (fig. 3 ).

In the western part of the province and adjoining parts of the Seward Peninsula, fold trends are predominantly north-south and northeast-southwest (fig. 3). The Devonian and older (?) metamorphic rocks of the Seward Peninsula appear to be thrust eastward onto Early Cretaceous andesitic volcanic rocks, and folds along the western margin of the province in the midCretaceous sedimentary rocks are overturned to the east. North of the Kaltag fault, fold trends are bent to the southwest, possibly by large-scale fault drag. South of the fault, a southwest regional grain persists as far as the Yukon delta.

Folds and faults in the eastern part of the province have a strong northeast-southwest orientation parallel to the southeast margin of the province. The east-west grain of the Brooks Range and Hogatza plutonic belt are deflected to the northeast in the northeastern apex of the province (fig. 3 ).

An attempt to fit the complex pattern of folds and faults in the northern Yukon-Koyukuk province into the regional structural framework of northern and western Alaska is shown in figure 10. Trend lines have been taken largely from the tectonic map of North America (King, 1969).

\section{BROOKS RANGE TRENDS}

The oldest folding is represented by the east-west Brooks Range trends, which affected nearly all of northern Alaska and the north edge of the Yukon-Koyukuk province. Deformation along these lines began in Late Jurassic with the rise of the ancestral Brooks Range and continued through Cretaceous (Patton and Tailleur, 1964, p. 493). In the northern Yukon-Koyukuk province, orogenic activity in Cretaceous time was manifest in the plutonic and volcanic activity along the Hogatza plutonic belt and in the east-west folding in the Kobuk and upper Koyukuk region.

\section{LISBURNE-SEWARD TRENDS}

The north-south trends along the western part of the province seem to be part of a broad slightly arcuate fold belt that stretches from Cape Lisburne southward through the Seward Peninsula and western YukonKoyukuk province to the Yukon River delta. A strong eastward-directed compression is reflected in the eastward thrusting of Paleozoic onto Mesozoic strata at Cape Lisburne (Campbell, 1967) and on the eastern Seward Peninsula and in the westward dip of axial fold planes in the Cretaceous strata in the western part of the Yukon-Koyukuk province. Deflection and over- 


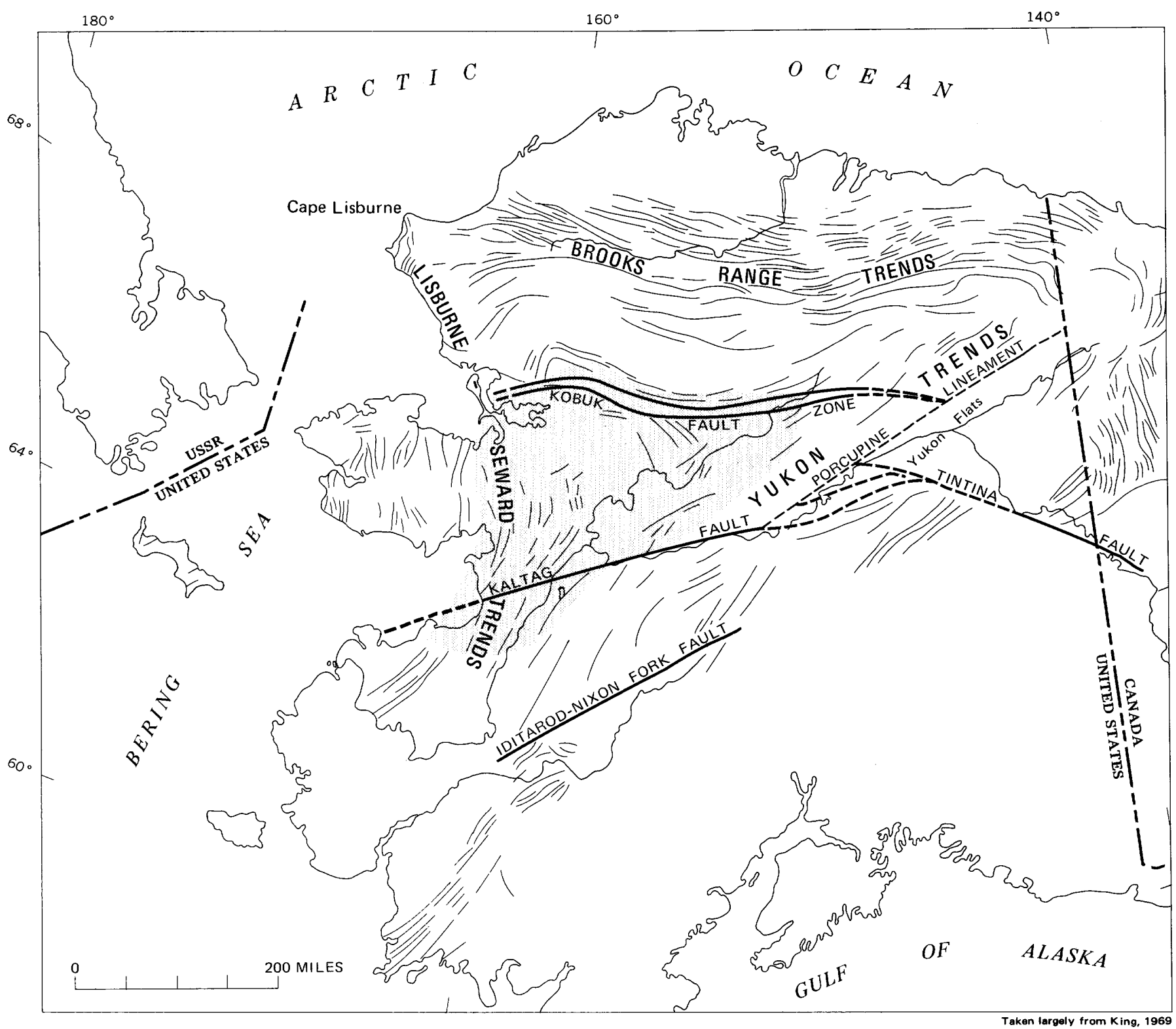

FIGURE 10.-Mesozoic and early Cenozoic structural trends in northern and western Alaska. Northern part of Yukon-Koyukuk province is shaded.

thrusting of east-west Brooks Range trends clearly indicate that these Lisburne-Seward trends are younger than Brooks Range trends, probably Late Cretaceous and early Tertiary.

\section{YUKON TRENDS}

Northeast-trending folds and faults along the southeastern margin of the province appear to be part of a broad band of northeast-trending structures that extend from the lower Yukon River through east-central Alaska into the eastern Brooks Range. To the southwest these trends merge with, and become indistinguishable from, the Lisburne-Seward trends. To the northeast they appear to deflect east-west Brooks
Range trends and die out in a conspicuous right-angle bend of the Brooks Range fold belt. The Yukon trends are clearly younger than the Brooks Range trends, but their relation to the Lisburne-Seward trends is uncertain.

\section{FAULTS}

\section{KALTAG FAULT}

The Kaltag fault has been traced for 275 miles across west-central Alaska from Norton Sound to near the mouth of the Tanana River (Patton and Hoare, 1968). Recent marine geophysical studies by Scholl and others (1970) suggest that it may continue another 200 miles southwestward across the Bering Sea shelf. The Kaltag 
fault transects the Yukon-Koyukuk province between Ruby and Unalakleet and appears to offset all major lithologic and structural trends (figs. 2 and 3). Province boundaries and geologic trends within the province appear to be displaced 40 to 80 miles right laterally (Patton and Hoare, 1968). The structural grain north of the fault in the western part of the province bends southwestward and intersects the fault at a small angle (fig. 3). This southwestward bend is accompanied by a marked increase in deformation of mid-Cretaceous strata and may represent large-scale fault drag. The major lateral displacement of Cretaceous and early Tertiary trends seems to have occurred before middle Tertiary time, but some movement has continued into Holocene time, as evidenced by local drainage offsets of as much as 1.5 miles (Patton and Hoare, 1968).

\section{KOBUK FAULT ZONE}

The Kobuk fault zone extends along the northern border of the province for 300 miles and may continue an additional 150 miles eastward to the Porcupine lineament (figs. 3 and 10). This zone of faulting, as much as 20 miles wide, is made up of numerous closely spaced high-angle fractures, only a few of which are shown in figure 3. The Kobuk trench, a narrow linear topographic depression which can be traced along the south edge of the Brooks Range from middle reaches of the Kobuk River eastward to the Yukon Flats, lies within the fault zone and appears to be a fault-controlled feature.

It has been suggested by Grantz (1966) that the Kobuk fault zone represents a major strike-slip fault, possibly the offset extension of the Tintina fault. Although no clear-cut evidence of lateral offset has been found, some large-scale horizontal dislocation seems required by major structural discontinuities across the fault zone. For example, along the lower Kobuk River, trends in the Brooks Range bend sharply southward to intersect the fault zone at nearly right angles (fig. 3). On the south side these trends are opposed by eastwest and northeast-southwest trends in the Waring Mountains. Farther east in the region of the central Kobuk River, a broad band of northwest-trending folds in the Cretaceous sedimentary rocks on the south side of the fault is cut off and opposed on the north side by east-west trends in the metamorphic rocks of the Brooks Range.

The age of the major faulting is thought to be latest Cretaceous or Tertiary, but some Quaternary movement is indicated by local rupturing of Pleistocene glacial drift (Patton and Miller, 1966).

\section{REFERENCES CITED}

Andreasen, G. E., 1960, Total intensity aeromagnetic profiles of Kobuk River, Alaska: U.S. Geol. Survey open-file report.
Barnes, D. F., 1969, Progress on a gravity map of Alaska: EOS, Am. Geophys. Union Trans., v. 50, no. 10, p. 550-552.

Bell, W. A., 1963, Upper Cretaceous of the Dunvegan, Bad Heart, and Milk River Formations of western Canada: Canada Geol. Survey Bull. 94, 76 p.

Bickel, R. S., and Patton, W. W., Jr., 1957, Preliminary geologic map of the Nulato and Kateel Rivers area, Alaska: U.S. Geol. Survey Misc. Geol. Inv. Map I-249, scale 1:125,000.

Brosgé, W. P., Lanphere, M. A., Reiser, H. N., and Chapman, R. M., 1969, Probable Permian age of the Rampart Group, central Alaska: U.S. Geol. Survey Bull. 1294-B, p. B1-B18.

Brosgé, W. P., and Reiser, H. N., 1964, Geologic map and section of the Chandalar quadrangle, Alaska: U.S. Geol. Survey Misc. Geol. Inv. Map I-375, scale 1:250,000.

Campbell, R. H., 1967, Areal geology in the vicinity of the Chariot site, Lisburne Peninsula, northwestern Alaska: U.S. Geol. Survey Prof. Paper 395, 71 p.

Dempsey, W. J., Meuschke, J. L., and Andreasen, G. E., 1957a, Total intensity aeromagnetic profiles of Hogatza uplift, Alaska: U.S. Geol. Survey open-file report, 1 sheet. $-1957 \mathrm{~b}$, Total intensity aeromagnetic profiles of Koyukuk, Alaska: U.S. Geol. Survey open-file report, 2 sheets. 1957c, Total intensity aeromagnetic profiles of west Hogatza, Alaska: U.S. Geol. Survey open-file report, 1 sheet.

Eakin, H. M., 1918, The Cosna-Nowitna region, Alaska: U.S. Geol. Survey Bull. 667, 54 p.

Fritts, C. E., 1970, Geology and geochemistry of the Cosmos Hills, Ambler River, and Shungnak quadrangles, Alaska: Alaska Div. Mines and Geology Geol. Rept. 39, 69 p.

Gates, G. O., Grantz, Arthur, and Patton, W. W., Jr., 1968, Geology and natural gas and oil resources of Alaska, in Natural gases of North America, pt. 1: Am. Assoc. Petroleum Geologists Mem. 9, v. 1, p. 3-48.

Geological Society of London, 1964, The Phanerozoic timescale: Geol. Soc. London Quart. Jour., v. 120, supp., p. 260-262.

Grantz, Arthur, 1966, Strike-slip faults in Alaska: U.S. Geol. Survey open-file report, $82 \mathrm{p}$.

Grantz, Arthur, Wolf, S. C., Breslau, Lloyd, Johnson, T. C., and Hanna, W. F., 1970, Reconnaissance geology of the Chukchi Sea as determined by acoustic and magnetic profiling, in Adkison, W. L., and Brosgé, M. M., eds., Proceedings of the Geological seminar on the North Slope of Alaska: Los Angeles, Pacific Sec. Am. Assoc. Petroleum Geologists, p. F1-F28.

Hollick, Arthur, 1930, The Upper Cretaceous floras of Alaska: U.S. Geol. Survey Prof. Paper 159, 123 p.

Imlay, R. W., and Reeside, J. B., Jr., 1954, Correlation of Cretaceous formations of Greenland and Alaska: Geol. Soc. America Bull., v. 65, no. 3, p. 223-246.

King, E. R., 1961, An aeromagnetic profile from Anchorage to Nome, Alaska: Geophysics, v. 26, no. 6, p. 716-726.

King, P. B., compiler, 1969, Tectonic map of North America: U.S. Geol. Survey, scale 1:5,000,000 (2 sheets).

Martin, G. C., 1926, The Mesozoic stratigraphy of Alaska: U.S. Geol. Survey Bull. 776, 493 p.

Mertie, J. B., Jr., and Harrington, G. L., 1924, The RubyKuskokwim region, Alaska: U.S. Geol. Survey Bull. 754, $129 \mathrm{p}$.

Miller, D. J., Payne, T. G., and Gryc, George, 1959, Geology of possible petroleum provinces in Alaska: U.S. Geol. Survey Bull. 1094, 131 p.

Miller, T. P., 1970, Petrology of the plutonic rocks of westcentral Alaska: U.S. Geol. Survey open-file report, 132 p. 
Miller, T. P., and Anderson, L. A., 1969, Airborne radioactivity and total intensity magnetic survey of the southern KobukSelawik Lowland: U.S. Geol. Survey open-file report.

Miller, T. P., Patton, W. W., Jr., and Lanphere, M. A., 1966, Preliminary report on a plutonic belt in west-central Alaska, in Geological Survey research 1966: U.S. Geol. Survey Prof. Paper 550-D, p. D158-D162.

Patton, W. W., Jr., 1966, Regional geology of the Kateel River quadrangle, Alaska: U.S. Geol. Survey Misc. Geol. Inv. Map I-437, scale 1:250,000.

1967, Regional geologic map of the Candle quadrangle, Alaska: U.S. Geol. Survey Misc. Geol. Inv. Map I-492, scale 1:250,000.

Patton, W. W., Jr., and Bickel, R. S., 1956a, Geologic map and structure sections along part of the lower Yukon River, Alaska: U.S. Geol. Survey Misc. Geol. Inv. Map I-197, scale 1:200,000.

$1956 \mathrm{~b}$, Geologic map and structure sections of the Shaktolik River area, Alaska: U.S. Geol. Survey Misc. Geol. Inv. Map I-226, scale 1:80,000.

Patton, W. W., Jr., and Hoare, J. M., 1968, The Kaltag fault, west-central Alaska, in Geological Survey research 1968: U.S. Geol. Survey Prof. Paper 600-D, p. D147-D153.

Patton, W. W., Jr., and Miller, T. P., 1966, Regional geologic map of the Hughes quadrangle, Alaska: U.S. Geol. Survey Misc. Geol. Inv. Map I-459, scale 1:250,000.

1968, Regional geologic map of the Selawik and southeastern Baird Mountains quadrangles, Alaska: U.S. Geol. Survey Misc. Geol. Inv. Map I-530, scale 1:250,000.

1970 , Preliminary geologic investigations in the Kanuti River region, Alaska: U.S. Geol. Survey Bull. 1312-J, p. J1-J10.

Patton, W. W., Jr., Miller, T. P., and Tailleur, I. L., 1968, Regional geologic map of the Shungnak and southern part of the Ambler River quadrangles, Alaska: U.S. Geol. Survey Misc. Geol. Inv. Map I-554, scale 1:250,000.

Patton, W. W., Jr., and Tailleur, I. L., 1964, Geology of the Killik-Itkillik region, Alaska: U.S. Geol. Survey Prof. Paper 303-G, p. G409-G500.

Payne, T. G., 1955, Mesozoic and Cenozoic tectonic elements of Alaska: U.S. Geol. Survey Misc. Geol. Inv. Map I-84, scale 1:5,000,000.

Quackenbush, L. S., 1909, Notes on Alaskan mammoth expeditions of 1907 and 1908: Am. Mus. Nat. History Bull., v. 26, p. $87-130$.
Sainsbury, C. L., 1969, The A. J. Collier thrust belt of the Seward Peninsula, Alaska: Geol. Soc. America Bull., v. 80, no. 12 , p. 2595-2596.

Sainsbury, C. L., Hedge, C. E., and Bunker, C. M., 1970, Structure, stratigraphy, and isotopic composition of rocks of the Seward Peninsula, Alaska [abs.]: Am. Assoc. Petroleum Geologists Bull., v. 54, no. 12, p. 2502-2503.

Scholl, D. W., and Hopkins, D. M., 1969, Newly discovered Cenozoic basins, Bering Sea shelf, Alaska: Am. Assoc. Petroleum Geologists Bull., v. 53, no. 10, p. 2067-2078.

Scholl, D. W., Marlow, M. S., Creager, J. S., Holmes, M. L., Wolf, S. C., and Cooper, A. K., 1970, A search for the seaward extension of the Kaltag fault beneath the Bering Sea [abs.]: Geol. Soc. America Abstracts with Programs, v. 2, no. 2 , p. 141-142.

Schrader, F. C., 1904, A reconnaissance in northern Alaska: U.S. Geol. Survey Prof. Paper 20, 139 p.

Smith, P. S., and Eakin, H. M., 1911, A geologic reconnaissance in southeastern Seward Peninsula and the Norton BayNulato region: U.S. Geol. Survey Bull. 449, 146 p.

Smith, P. S., 1913, The Noatak-Kobuk region, Alaska: U.S. Geol. Survey Bull. 536, 160 p.

Steinmann, A., 1926, Die ophiolitischen zonen in den Mediterranean Ketlengebirgen: Internat. Geol. Cong., 14th, Madrid, Comptes rendus 2, p. 638-667.

Tailleur, I. L., 1970, Lead-, zinc-, and barite-bearing samples from the western Brooks Range, Alaska: U.S. Geol. Survey open-file report, $16 \mathrm{p}$.

Tailleur, I. L., Brosgé, W. P., and Reiser, H. N., 1967, Palinspastic analysis of Devonian rocks in northwestern Alaska, in Oswald, D. H., ed., International Symposium on the Devonian System, Calgary, 1967, v. 2: Calgary, Alberta Soc. Petroleum Geologists, p. 1345-1363.

U.S. Coast and Geodetic Survey, 1965, Total intensity chart of the United States, 1965.0-Lines of equal magnetic total intensity and equal annual change (United States Chart 3077f): U.S. Dept. Commerce, scale 1:5,000,000.

U.S. Geological Survey, 1971, Ophiolites in the Bettles and Wiseman quadrangles, in Geological Survey research 1971: U.S. Geol. Survey Prof. Paper 750-A, p. A51-A52.

Zietz, Isidore, Patton, W. W., Jr., and Dempsey, W. J., 1959, Preliminary interpretation of total-intensity aeromagnetic profiles of the Koyukuk area, Alaska: U.S. Geol. Survey open-file report, $7 \mathrm{p}$. 
